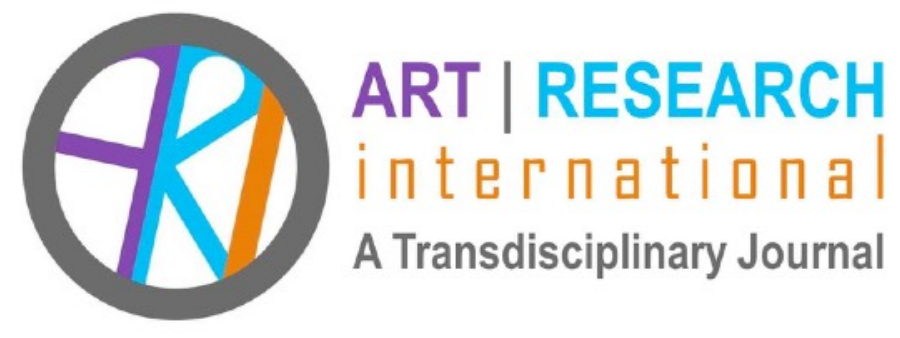

\title{
STORYMAKING BELONGING
}

Tracey Bunda

University of Southern Queensland tracey.Bunda@usq.edu.au

Robyn Heckenberg

University of Southern Queensland robyn.Heckenberg@usq.edu.au

Kim Snepvangers

The University of New South Wales, Sydney: Art \& Design

k.snepvangers@unsw.edu.au

Louise Gwenneth Phillips The University of Queensland louise.phillips@uq.edu.au

Alexandra Lasczik Southern Cross University lexi.lasczik@scu.edu.au

Alison L. Black University of the Sunshine Coast ablack1@usc.edu.au 
Tracey Bunda is a Ngugi/Wakka Wakka woman and Head of the College for Indigenous Studies, Education and Research at the University of Southern Queensland. Tracey has worked in the field of Indigenous Higher Education for over 30 years during which time she has led Indigenous higher education. As a critical theorist, her research focuses on institutional and ideological positions that inform relationships with Aboriginal and Torres Strait Islander peoples and she sees this work as foundational to the process of de-colonisation. Tracey's most current work takes a creative re-direct to investigate the ways in which research can be framed through storying.

Robyn Heckenberg is a lecturer in Indigenous Studies, College for Indigenous Studies, Education and Research. She is a Wiradjuri woman and member of Possum Dreaming. Her research interests include Aboriginal and Torres Strait Islander Cultural Studies inclusive of Environmental Knowledge, Art Theory and Criticism. As a visual artist she has particular theoretical concern for the ways in which Country can be cared for, taking account of place pedagogy through river history and Wiradjuri missions. Her creative work extends to exhibitions and artistic interpretation of place - see the Yindyamarra Sculpture Walk, Murray River, Albury. Robyn is a Member of Art Education Australia (AEA), Society of the History of Emotions (formerly CHE) and the Australian Association of Research in Education (AARE).

Kim Snepvangers is Associate Professor and Director, Professional Experience \& Engagement Projects at UNSW Sydney: Art \& Design. As the recipient of a recent UNSW Strategic Educational Fellowship: New Approaches to the Development of Professional Identity through Independent Critical Reflection, her research interweaves creative and professional industry contexts. Working with Indigenous collaborators and cultural mentors on exhibition projects engages her history with dissensus to challenge dominance of progress narratives. Her research engages visualisation with creative ecologies, critically reflective frameworks and embodied pedagogies. She has extensive research experience in developing transitional educative spaces between academic, creative and professional practice. https:// artdesign.unsw.edu.au/about-us/our-staff/dr-kim-snepvangers

Louise Phillips is a fifth generation white Australian, who teaches and researches in the School of Education at The University of Queensland. Louise's career spans theatre in education, early childhood education, storytelling, environmental education, children's rights and citizenship research, and arts-based research methodologies. She is particularly interested in story as theory and method illustrated through co-authoring the Routledge book Research Through, With and As Storying with Tracey Bunda. Her work also seeks inclusion of children's political rights see http:/l thewalkingneighbourhood.com.au and the Routledge 2019 co-authored book Young 
Children's Community Building in Action: Embodied, Emplaced and Relational Citizenship. http://louptales.education

Alexandra Lasczik (formerly Cutcher) is Associate Processor, Arts \& Education, in the School of Education, Southern Cross University, Gold Coast Campus. She is currently Research Leader and founder of the Creativity, Arts and Education Research Group (CreAre) and Chair of the Arts-based Educational Research (ABER) SIG for the American Educational Research Association (AERA). Alexandra was recognised nationally for her teaching and research in Visual Arts education, most recently as a recipient of a prestigious OLT (Office for Learning and Teaching, Australian Government) Citation for Outstanding Contribution to Student Learning. Her work synthesises the Arts, teaching and research, and she is best known as an ABER methodologist. In 2016 she was awarded Southern Cross University, School of Education Researcher of the Year. https://works.bepress.com/alexandra_cutcherl

Ali Black is a narrative researcher and early childhood educator. Her arts-based research and scholarly work fosters connectedness, community, wellbeing and meaning-making through the building of reflective and creative lives and identities. Ali's storied and visual methodological approaches dismantle personal/professional binaries to re-present the lived life. Her research and writing highlights the transformative power and impact of collaborative and relational knowledge construction. https:// www.usc.edu.au/staff-repository/dr-ali-black

Abstract: Sometimes data invites more of us. To be physically held and touched, through hands creating and crafting with matter, cultivating a closer connection to the fibres, threads, textures and sinews of data. Through touching and shaping the materiality of data, other beings, places and times are aroused. Here, we share the story of data that invited more of us and how this has spurred the creation of an exhibition titled Stories of Belonging with Indigenous and non-Indigenous artist/scholars for an arts festival in Queensland, Australia. This work by the collective, SISTAS Holding Space, deeply interrogates our ontological positionality as researchers, in particular what this means in the Australian context - a colonised nation populated through waves of migration. The scars of colonization, migration and shame are held and heard through Black and White Australian women creating and interrogating belonging alongside each other - listening and holding space for each other. We air the pains of ontological destruction, silencing, disconnection and emptiness. Through experimental making research methodology, we argue the primacy of storying and making, and for provoking resonant and entangled understandings of belonging and displacement.

Key words: Indigenous women; White women; storying; belonging; ancestry; place; making; stitching 


\section{Searching Archives: Locating Place and Story}

In writing the book Research Through, With and As Storying (Phillips \& Bunda, 2018), Tracey and Louise located themselves in place and ancestral storying. The provocation to do so led them both to search archives for ancestors' stories. There are few stories in archives; instead, scientific dehumanized records dominate. Record keepers' clinical interpretations track, categorise and surveil. In order to reclaim, disrupt and humanise the archives Tracey and Louise created with archival data, together and separately. First is the story of making the basket of archives:

Tracey: In a previous life, somewhere between teaching in the classroom and working in the university, I was employed in the Aboriginal and Torres Strait Islander Branch of the Queensland Education Department. Part of my role was to assess the quality of resources that would support the teaching of Aboriginal and Torres Strait Islander studies in the school curriculum. I recall a film resource which showed basket making skills used by Aboriginal women in the north of Queensland. I set about, with imperfect remembering, making this basket.

I am fascinated and perplexed by the gardening design uptake of palm trees where I live. I think these plants belong in the tropical north. Regardless, palm trees are an established feature in modern urban design and, with the generosity of the westerly wind and my neighbour's palm trees, a palm frond was delivered into my back yard.

To create the basic rectangular pattern for the basket I first sawed off the stem and frond. What was left was the sheath, that part which wraps around the trunk of the palm tree. The sheath was hard and unforgiving. So, in order to work with this stiff fibrous material, it needed to be made malleable by being wet. I submerged the sheath in my bathtub, and weighed it down with a cast iron pot so that it could be thoroughly soaked. (The cast iron pot left an imprint in the fibre and though I was initially disappointed, my colleague Robyn, who as an academic artist, saw the stain of the pot as adding value to the design. Blessed be artists for seeing the world differently.) After a few days, I took the sheath from the water. At the longest edges, I folded the sheath inwards about $2 \mathrm{~cm}$ to make a seam. I then folded the sheath almost exactly in half. One half was longer by approximately $5-6 \mathrm{~cm}$. Along the edges of the basket I punched holes with a nail at equidistance so that I could stitch the edges together. For this, I used jute in a cross-stitch pattern. I added some decoration to the basket by sewing in the eucalyptus nuts which I had painted and threaded with jute. I plaited a jute strap for carrying the basket (the strap can be placed around your forehead like a head-band and when carried in this way allows the basket to nestle on your back between your shoulder blades and leaves your hands free for gathering). The strap can also be used 
for hanging the basket. The finished basket was oiled, to help in the preservation, and to mimic the transfer of body oil from person to basket, such as would have occurred if it were a basket in use at the time of BC (Before Cook). ${ }^{1}$

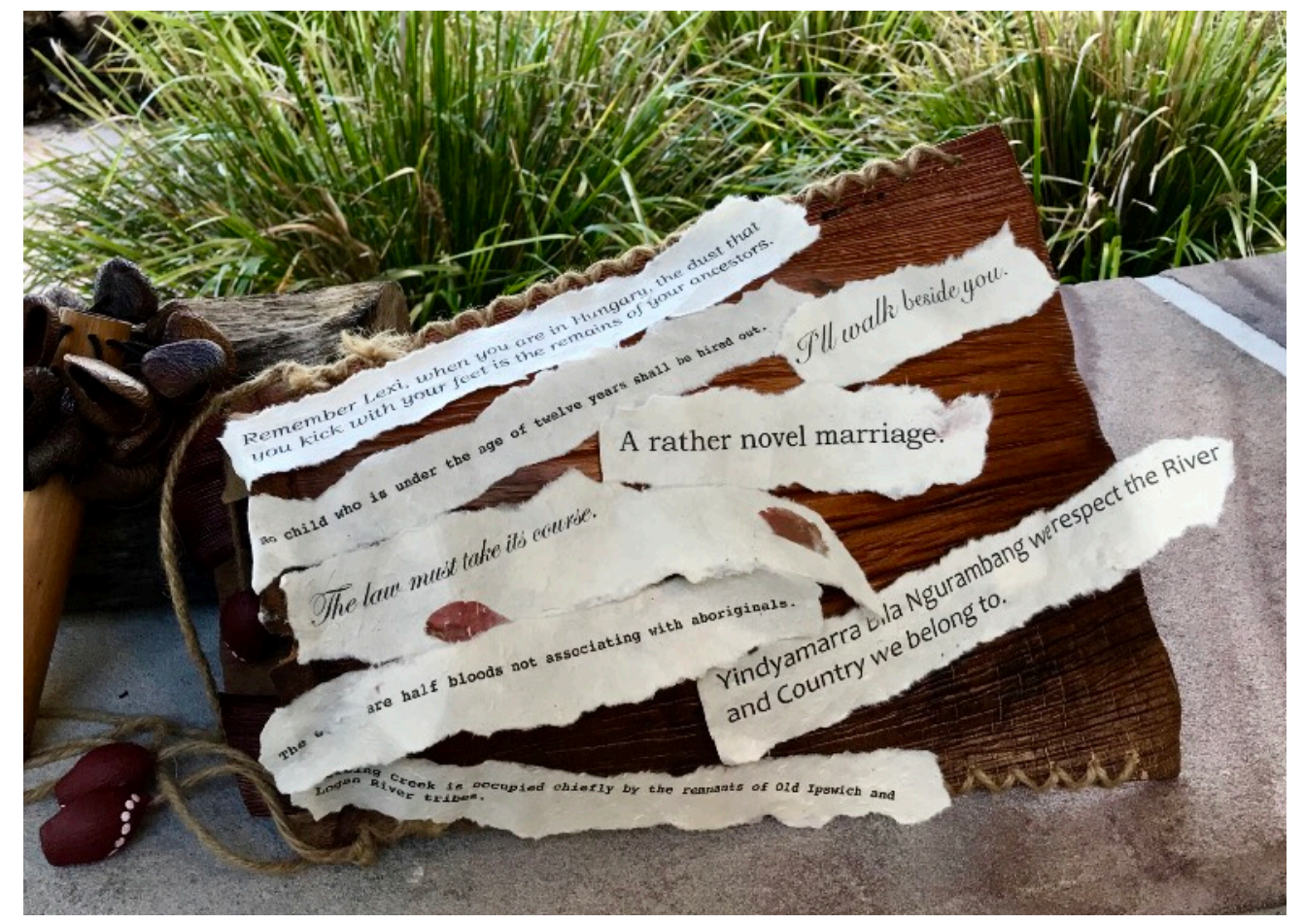

Figure 1. Basket holding and (re)claiming archives, original artwork by Tracey Bunda

The photograph shows a series of words and phrases coming to lay across the fibrous front of the basket. These phrases and words are taken directly from our archival research, in part, from those stories told to us by family of our ancestral roots. And holding that knowledge and reclaiming that knowledge through women's crafts, of needle penetrating fibre to (re)present, the basket and archival documents meld to present our storying research, moving through time and place to dig deeper, to critically examine and to imagine lives. There is a cathartic effect as hooks (1995) notes, "...to tell one's story and the process of telling is symbolically a gesture of longing to recover the past in such a way that one experiences both a sense of reunion and a sense of release" (p.158).

When storying is organic, embodied - through seeing, hearing and feeling - in becoming and known, recited, remembered and recalled - emergent conditions coalesce, to form in thought, to speak anew the colonial texts that would make our ancestors disembodied, as if separate from the times and ideologies that would place them as less than human. We re-story 
their lives, by tearing up the archival scripts, drawing from our theoretical baskets, imagining a differing humanity for those from which we come. (Phillips \& Bunda, 2018, pp. 19)

Following the re-territorialisation of archives in the basket, Tracey and Louise then decided to curate an exhibition of making with archival data troubling belonging in the colonial nation Australia. They invited artist researchers known to them, Robyn, Kim, Lexi, and Ali to contribute artworks and accompanying performances to the performative exhibition, which became titled "Stories of Belonging" and was performed in the Kuril Dhagun Talking Circle at the State Library Queensland as part of the Anywhere Festival 2018. Together the Black and White Australian women provoked resonant and entangled understandings of belonging and displacement through performative making with storied archival data. This article shares how each of us engaged with making as method, and what we unearthed as we engaged with the provocation of belonging as Australian women.

Now prepare to take in Tracey's storymaking of belonging.

\section{Blood Quantum}

During the course of producing my $\mathrm{PhD}$ I came to understand that the expectations of "academic rigour and research" required time, isolating time, lost in textbooks, alone in libraries, lost in my head, conversations with white male theorists (some of whom have passed but are still speaking), trying to apply newfound concepts, playing with words and meanings. This was first step interrogation of the literature. With assured stumbling I travelled to other theorists, journeying into the theoretical voices of coloured, black, the othered and women. Feminist, black, coloured and othered articulations spoke to me, into me, wrapped around me with nurturing comfort, producing in me the courage to find voice and ask questions, to come to realisations that acts of colonization may capture the land and the body but they also capture the mind. Almost. All most. Most all. Most of the voices that speak of us, and of our positioning, that are given authority, are predominately white. But, we have our own stories. And it was these stories that I wanted to bring to the doctoral page, carefully crafting words to pay homage to the old people who would eloquently tell and perform the stories, respectfully replicating original tellings, black words on white pages. Can you see the theory, hear it, feel it? The stories exude the knowledge of those old weavers of words. Some have passed but are still speaking on the page. What is Aboriginal Knowledge if it does not have its essence in theorizing from our view of the 
world? I centred the words from the old people in the text of the thesis, and at the commencement of each chapter, authorizing this knowledge to be the platform from which I could speak, speaking back, a counter-theorizing of the world I was examining. A different method, to make anew, to reclaim and reshape. Yes, there is more than one method to make the world.

I gave my daughter her matrilineal Grandmother's story, the one where she was taken. Taken from her family. Taken in the light of day. Taken with her older brother and sister. Taken under the auspice of some gammon gammon ${ }^{2}$ legislation, dughai ${ }^{3}$ imagined truth talking. Is there a truth for Aboriginal peoples when the colonizer speaks? I asked my daughter whether she could make the story through her method to choreograph the story into dance work. Ngioka (Oka) lovingly took her Grandmother's story and nurtured this story into dance steps, movements and gestures for herself and two other dancers with the three representing her relationalities to Grandmothers (Grandmother and Great Aunty) and Grandfather/Great Uncle. Her sister Angelina painted the background artwork. Oka and Angie listened carefully to the story, taking those black words from the white page onto the canvas and dancefloor. In the translation to the different form, Oka chose to re-name the story which I had titled "Taken" to "Blood Quantum." Oka's re-naming laid bare a questionable truth of the colonizer's view of the world - that is, the authority of white science to measure value and worth in the membership of race. Race. Racing.

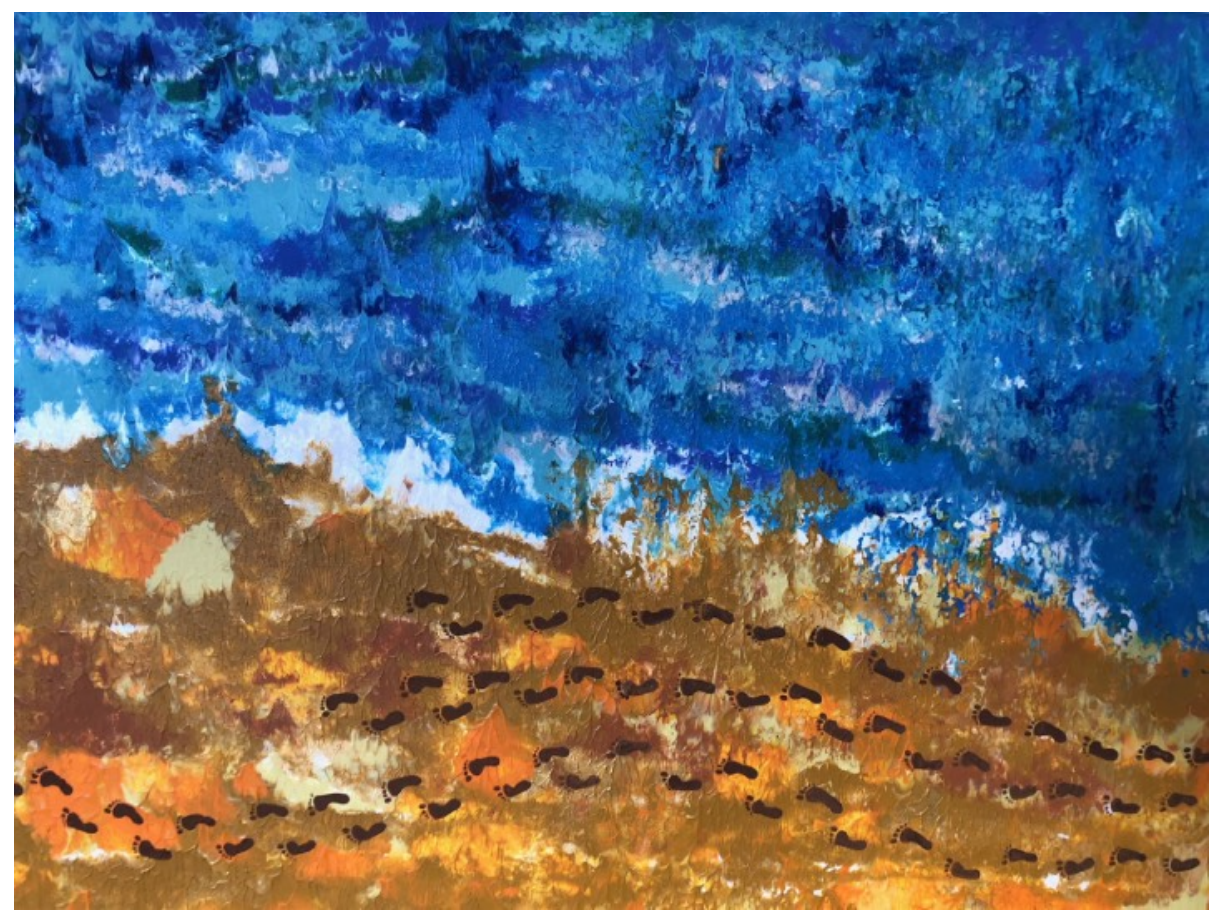

Figure 2. Taken, original artwork by Angelina Parfitt 
A canvas of brightness, strong blues of the sea and sandy yellows of the beach where the children's footsteps left imprints - almost the length of the beach - and then disappeared. Taken. This image projected onto a multi-screened wall was the backdrop for the dancework. Blood Quantum commenced with a meld of the three dancers clutching each other tightly. Terrorized children frightened to let go. Reluctantly separating as individuals, the dancers positioned themselves in the dance space, moving through the choreography in unison and individually taking cues from the storying of Blood Quantum orated by myself. A recorded musical accompaniment melded with the gestures, steps and drama of the moments. Blood Quantum ended as it began with the melded three, tightly clutching, terror in

\section{the blood.}

Hold Tracey's storymaking of belonging.

Breathe...

Now prepare to take in Robyn's storymaking of belonging.

\section{Yindyamarra Bila Yiramal, Ngurambang Milawa Wirramarri, Maranggaal}

I begin: Now Winhangara Listen, Yindyamarra, Carefully - as river music plays, echoing the river's babbling and meandering.

My story is about belonging to and respecting the river and the riverbank. The performance was accompanied by river music written and performed by young Wiradjuri man (Heckenberg, 2018).

The River is home for fish, tiny creatures; all of nature abounds. It gives us spiritual sustenance. Murray Cod and the Giant River Redgum are teachers and fellow travellers. The rivers are the lifeblood of our Country, flowing through our ancient Wiradjuri land (Heckenberg, 2016). With Yindyamarra, we venerate the quiet solitude of the river, hear the sounds of our children and fellow creatures from time before time, the stories of our river and our kin, kinship and totem relations, looking after the spirit and the body, gathering our stories, holding our knowledge. Yindyamarra respects our Country and our Rivers. Giant River Red gum teaches patience and fortitude. Giant Murray Cod inspires relationships and rejoicing in survival, learning to persevere, communicating right-way knowledge to foreign mores of seemingly irresolvable 
company. Yindyamarra teaches to go lightly and carefully, respectfully share with those who can help look after our rivers and environment with Yindyamarra. My devotion is that one day all will understand Yindyamarra and the sacred space of the Murray Cod and River Red gum and all our living creatures. The ideal of Caring for Country - Sky, Land and Water - has been a recurring philosophy and theme within an Indigenous dialectic of Earth care; the Wiradjuri people have a sense of belonging to their land and rivers, which includes duty of care.

This notion materialised as a wearable piece of art. I created a gown in white gossamer shimmering material representing a spiritual aspect of nature, and the lifeways of River Red gum and the Murray Cod in particular. A giant River Red gum tree trunk made with velvet came up the middle of the garment. Poking out of one side of the tree, from a hollow branch was a smiling possum with big sparkling eyes. This referenced a possum, our clan totem, that lives that way at Mungabareena Reserve on the banks (yiramal) of the Murray River. Another animal is appliqued on the base of the trunk: this is a lovely brown snake curled up with her energetic snakelets. Attempting to stay invisible, but immediately obvious by its bright plumage, is a duck standing adjacent to the River Red gum tree trunk. All of these animals represent totems and animals from near the river. They are drawn onto the gossamer gown, not by pencil, but by thread. They are appliqued into the environment and represent energies in nature. There are leaves of satin sewn and hanging from the gown everywhere round, as is the bush and forest itself. Further to this, also represented are a number of fish species: they all glisten with their individual shiny scales, brought to life through the texture of the fabric used. There are Catfish, Spangled Perch, Macquarie and Golden Perch, Murray Cod, and a brilliantly sparkling Short Finned Eel. Tiny little Olive Perthet fish travel as a school within the environment created on the gown. Atop all of this is a halo of leaves created as a cape, symbolizing a canopy for the River Red gum. The Cape also references the significance of such garments to many Indigenous people. As one coming from a tradition relating to possum totem, our clan would have had magnificent capes from Kangaroo fur, much like those made by contemporary artist Badger Bates, who is a Barkindji man, neighbour to Wiradjuri, my people. The other references to capes are the exquisite ones made by the Polynesians of Hawaii who used the feathers of birds of paradise, and birds unique to their islands, to adorn Kings and Princes. Up the back of the gown is a huge Goanna (Googar) which is a tribal totem, showing strength and purpose in nature, and strength and purpose in our voices telling the story of nature and its need to be protected. This is my message in constructing my artwork through craft practices, and this is the story told as part of the Anywhere festival: Stories of Belonging: Sisters Holding Space.

As I feel a visceral sense of my belonging, I embrace my emotion, listening to the river music, resonating the river message and annunciate: 
Within that balance are the teachings and dignified way of ANCESTORS;

From the metaphysical realm of the DREAMING and the Traditional Spiritual Values and immutable Law, the beliefs and principles of Yindyamarra employ the teachings of the Old People and the Laws of the Ancients.
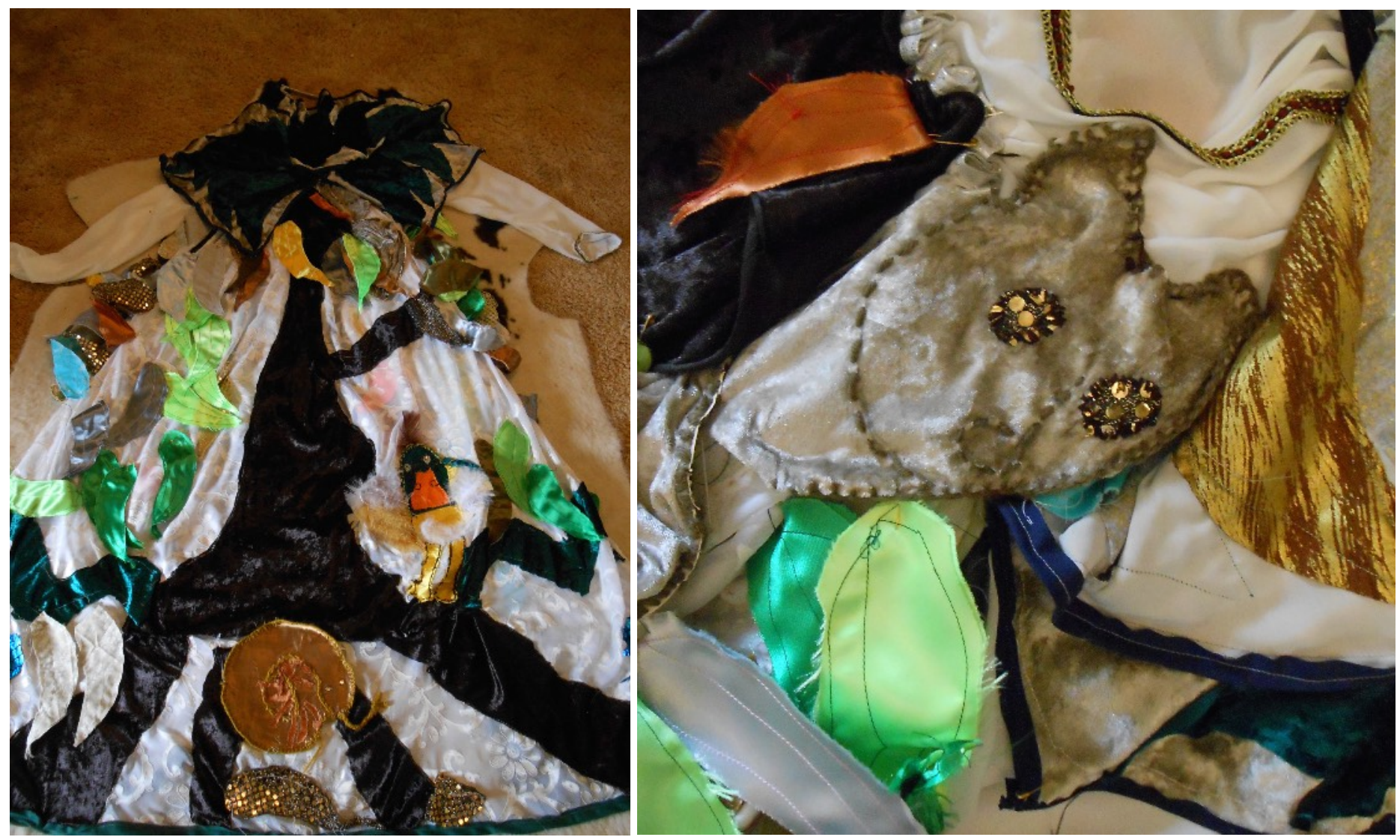

Figures 3 \& 4. Yindyamarra Bila Yiramal, Ngurambang Millawa Wirramarri, Maranggaal, original artwork by Robyn Heckenberg

This image of possum is an applique on the garment worn in the river performance. Possum is Robyn's clan totem, to be protected and celebrated.

Hold Robyn's storymaking of belonging.

Breathe...

Now prepare to take in Kim's storymaking of belonging. 


\section{A Rather Novel Marriage}

A rather novel marriage, illuminates an emergent story about Indigenous and non-Indigenous Australia. To investigate questions of storying and belonging, the public reporting of the 1848 marriage of my Great Great Grandfather (GGGF) Black Harry, in a Sydney Morning Herald ( $\mathrm{SMH}$ ) article, is used as a catalyst. The SMH is still one of the largest circulation newspapers in Australia. In the absence of paternal family photos and artefacts, more typical of my maternal lineage, that article is a moment in time, and one trace of my ancestor. As a recently uncovered material artefact, this facsimile of the original newspaper sits alongside a few other publicly reportable exploits of Black Harry. My grandmother when asked "Nan, are you Aboriginal?" always insisted that she/we were Spanish. Her response never wavered. She always responded with a polite "No, we are Spanish". This was a colour-coded denial designed to deliberately hide her Aboriginal ancestry. There is no evidence of anyone being Spanish. At this point in time, this is the only available knowledge I have, clearly iterative, non-linear memories and copies. The "discovery" of the artefact that was always there, is part of my uncovering of entangled histories of denial of Aboriginal ancestry and culture that is only just now being brought into the light. This is where the four slim LED lightboxes on red and white backlit film in my performance come in, using selected text from the SMH article, to shed light on quasiacceptance of diversity as "novelty" and "industriousness". Text is illuminated on the stacked lightboxes, to focus on colour and commodified domesticity, and beam welcoming messages to visitors who come to my home.

The 12 December SMH article was titled: "Marriage of an Aboriginal" and was situated alongside newsworthy regional colonial interests at the time: Small Debts Court, Lunatic, Medical Profession and The Railway. On Wednesday 6 December an Aboriginal black man had stood alongside his white partner, at Sutton Forest, near Mittagong in the southern highlands of New South Wales, an intermarriage, one of only a handful reported in colonial Australia. For the creation of the artwork, A rather novel marriage, and to countermand progress and discovery narratives, I received guidance from cultural mentors, Tess Allas and Tracey Bunda, to distil some text from the article for contemporary visibility. These comprising: 
A rather novel marriage an aboriginal black to a white woman. commonly called Black Harry He is very intelligent and industrious.

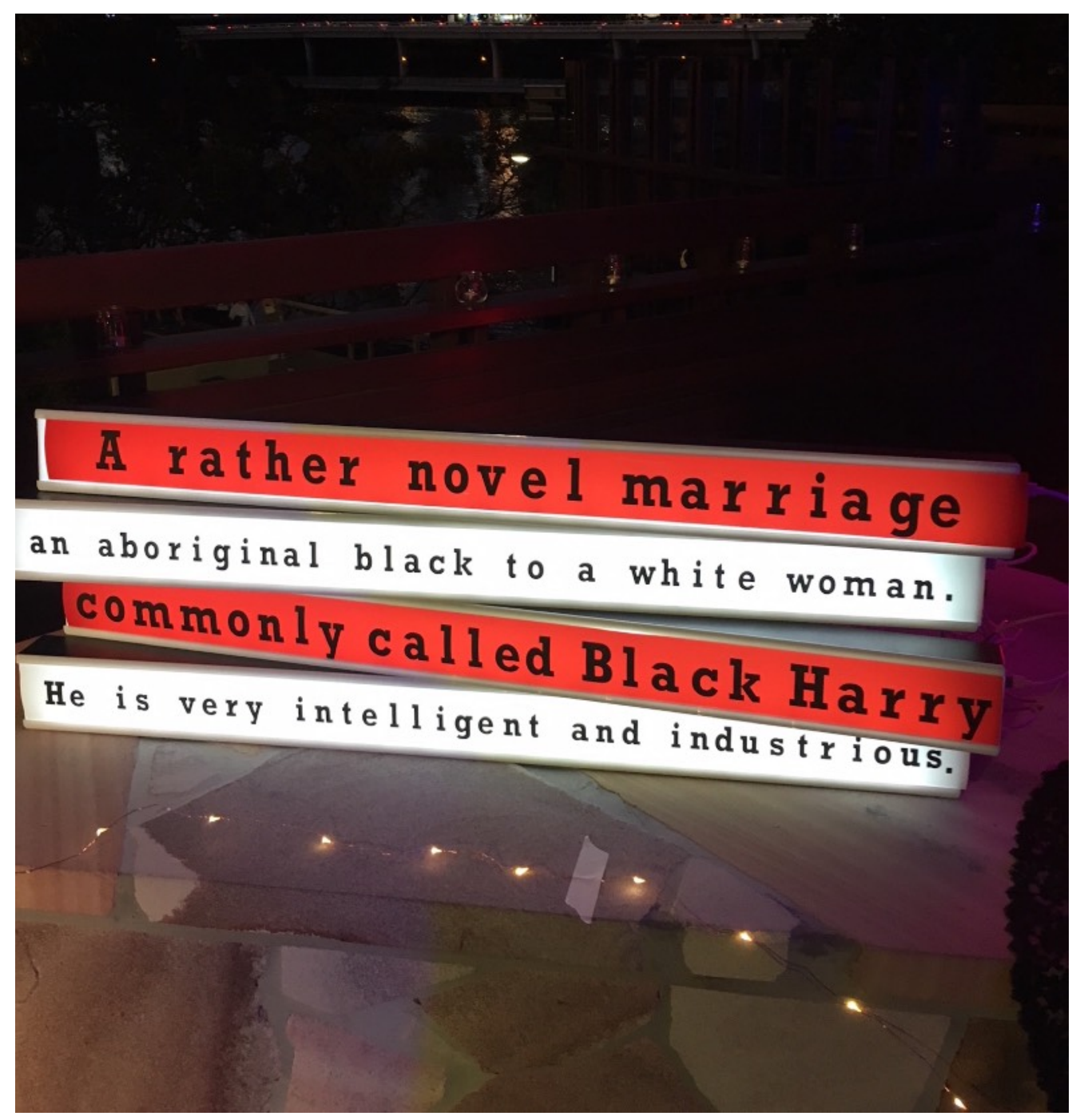

Figure 5. A rather novel marriage, original artwork by Kim Snepvangers.

So, what is the novelty being displayed here? Novelty implies difference, newsworthiness and a type of quasi-acceptance, a way to be welcomed into white society, yet not quite. Qualifying biosocial terms such as intelligence and industriousness are used as a type of behavioural justification for the marriage. Perhaps the novelty of this marriage was how such qualities were perceived by white people as not being applicable to Aboriginal people. The second component of the stitching 
performance re-stitches the selected text from the 1848 marriage onto a newly created artefact, a black domestic apron. My maternal Great Great Grandmother, Catherine Theresa Underwood, brought a black Victorian mourning apron embroidered with red and green flora of a Rowan tree, from Ireland on a 100- day journey from Europe to Australia in 1853. This important artefact signalling the sadness of death, inevitability and the wretchedness of never seeing home and loved ones again was passed to me through my maternal family. The apron was not used every day, rather saved, as per Victorian mourning custom for wearing for some time beyond the funeral to signal the wearer's unavailability for marriage. The artwork combines the celebratory whiteness of marriage (1848) in contrast with the darkness of this black Victorian mourning apron (1853) in a stitching performance. I recreated the apron as a way to re-stitch and embody my ancestors back into history, my Aboriginal and Irish ancestry in a new wordly sensibility.

The stacked lightboxes, when combined with a stitching performance in the presence of my Great Great Grandmother's mourning apron, allow me to recreate sutured histories in a "very industrious" manner, with the embroidered embellishments deliberately unfinished. Re-stitching actively interweaves micro-narratives of darkness and lightness with contemporary resonance. The artwork engages two fragmentary, yet celebratory, significant moments: a marriage and a marker of mourning for loss of ancestry, lives and belonging. A key question that arises is "Where do you belong?" particularly if your paternal ancestry is shrouded in darkness, with little information available about the history of intermarriage and Aboriginal ancestry. The stitching performance conceived as an encounter, brings previous entanglements and being into current receptivity.

Hold Kim's storymaking of belonging.

Breathe...

Now prepare to take in Louise's storymaking of belonging.

\section{Etch, Stitch: I Am a Colonial Subject}

I am not proud to call myself Australian and I believe white Australians need to interrogate what it means to call ourselves Australian.

We are diaspora, with unknown uncertain homelands.

Where do we come from?

This question demands "white Australians to respond by situating ourselves philosophically in relation to our origins...as the only thing that is our very own" (Nicolacopoulos \& Vassilacopoulos, 2014, p. 15). Origins only offer some answers 
to our out-of-placeness. White Australians need to face the naming of our relations to the spaces we inhabit. Why are we here?

In interrogating my Australian identity and locatedness, I went back to archives of my ancestors who were transported to Australia as labour and breeding cargo. A perverse chapter in the nation building project of white Australia is the convict experience. Though now convict ancestry is glorified as the "humble beginnings of a greatly successful social experiment" (Nicolacopoulos \& Vassilacopoulos, 2014, p. 19), my grandfather did not tell my mother and her siblings that his grandparents were transported convicts. It was only in the 1970s that it became "fashionable" for the convict stain to see the light of day. In the 1830s/40s, my mother's father's grandparents were transported as teenage convicts to Van Diemen's Land, to be forced occupiers of stolen land.

In locating the surgeon's journal record of my Great Great Grandmother Nancy Ann (from the ship which sent her to Van Diemen's land), I was compelled to do more than reading, more than thinking, more than writing. I was compelled to touch the matter of data, to hold its form, to shape, to pull, to pinch, to cut, to penetrate, to submerge with its essence. It was an encounter of "entangled relation of data-and-researcher" that MacLure (2013) writes on in the wonder of data, when "the inert corpus (corpse) of the data, ...grasp[s] us" (p. 228).

Nancy Ann's description was scientifically recorded, as were all of her physical features, including "C C S P M A M C and W M above elbow on right arm and R R M R S R T R J D and two hearts above elbow on left arm" (Libraries Tasmania Online Collection, n.d., CON19-1-3 image 135).

I read up on convict tattoos.

I retraced Nancy Ann's footsteps in the town of her displaced incarceration - Hobart. I sat and held this piece of data and wondered on the stories of her tattoos.

"Wonder is...preeminently material: it insists in bodies as well as minds" (MacLure, 2013, p. 229).

I needed to do more. It was not about knowing why the tattoos and what the initials represented, that was Nancy Ann's intimate story. Rather I sat with the not knowing - the liminal - the uncertainties - to feel the experience of not knowing (see Pink, 2015). I had the burgeoning urge to hold and touch - prompted by ethicality rather than the thirst for cognitive knowledge. Through making, I wanted to be with the sensation, affects and intensities (Deleuze, 1990) of the penetration of flesh and to honour and reclaim the sovereignty of these body markings. 


\section{I sought to offer tenderness.}

I found a remnant piece of fine white cotton in my fabric collection. I cut and ripped a strip suggestive of an armband. I mourned for her violated life. The armband claimed visibility of the horror and pain of her violation.

I sensed every cut for every line of each inked initial ingrained into her skin. I held the puncturing of needle into flesh through stitching the initials into the strip of cotton. Though the initials are representational - the intent was not to accurately represent, but instead to hold each line of each initial - it was about the endurance and the form.

On completing the 10 initials for the right arm band and the 10 initials and two hearts for the left, I pulled at the weft and warp threads with a felting needle to embody and hold the ongoing abuse - the wear and tear of a harsh life.

I drank tea whilst I stitched,

then submerged the cloth in the remnants, sharing fluids,

sharing staining.

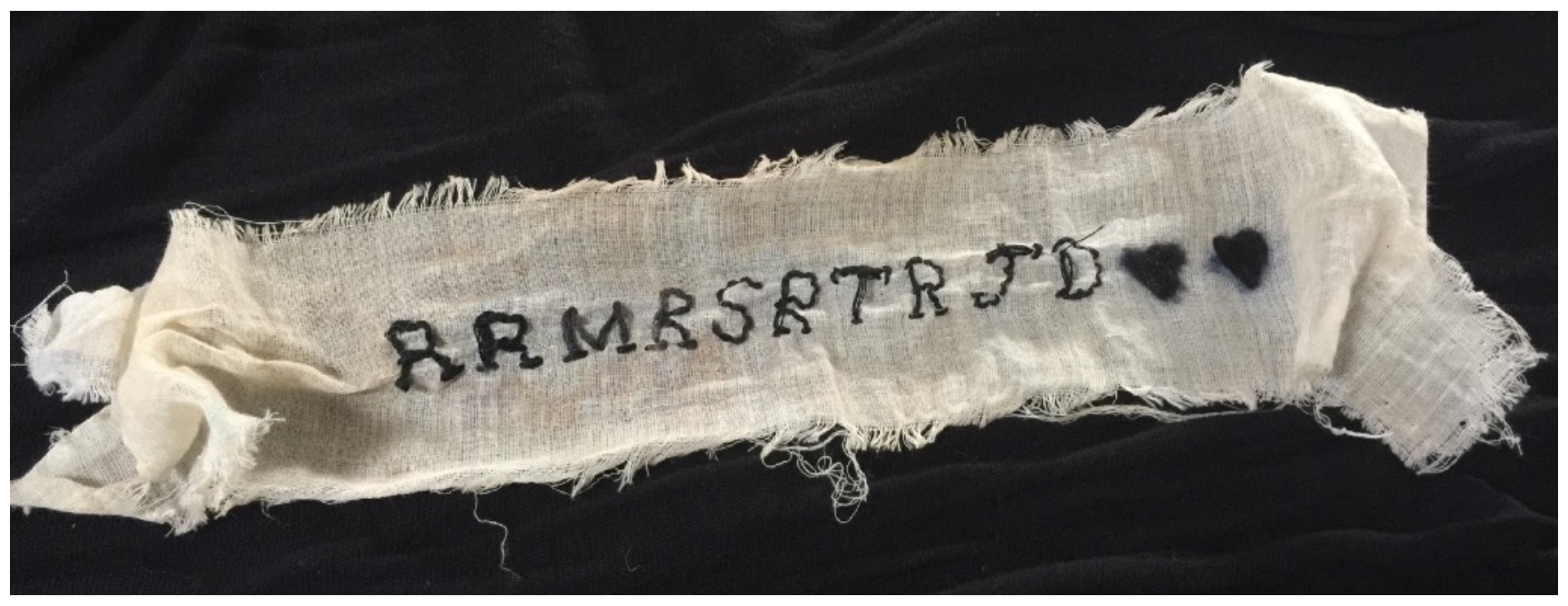

Figure 6. Nancy Ann's left arm (re)marks, original artwork by Louise Gwenneth Phillips 
Then later for the Stories of Belonging performance, I sewed coarse calico skirts and bonnets, soaked in tea and onion juice and beaten on rocks and hand twisted. To feel against my skin, cloth likeness that touched my Great Great Grandmother.

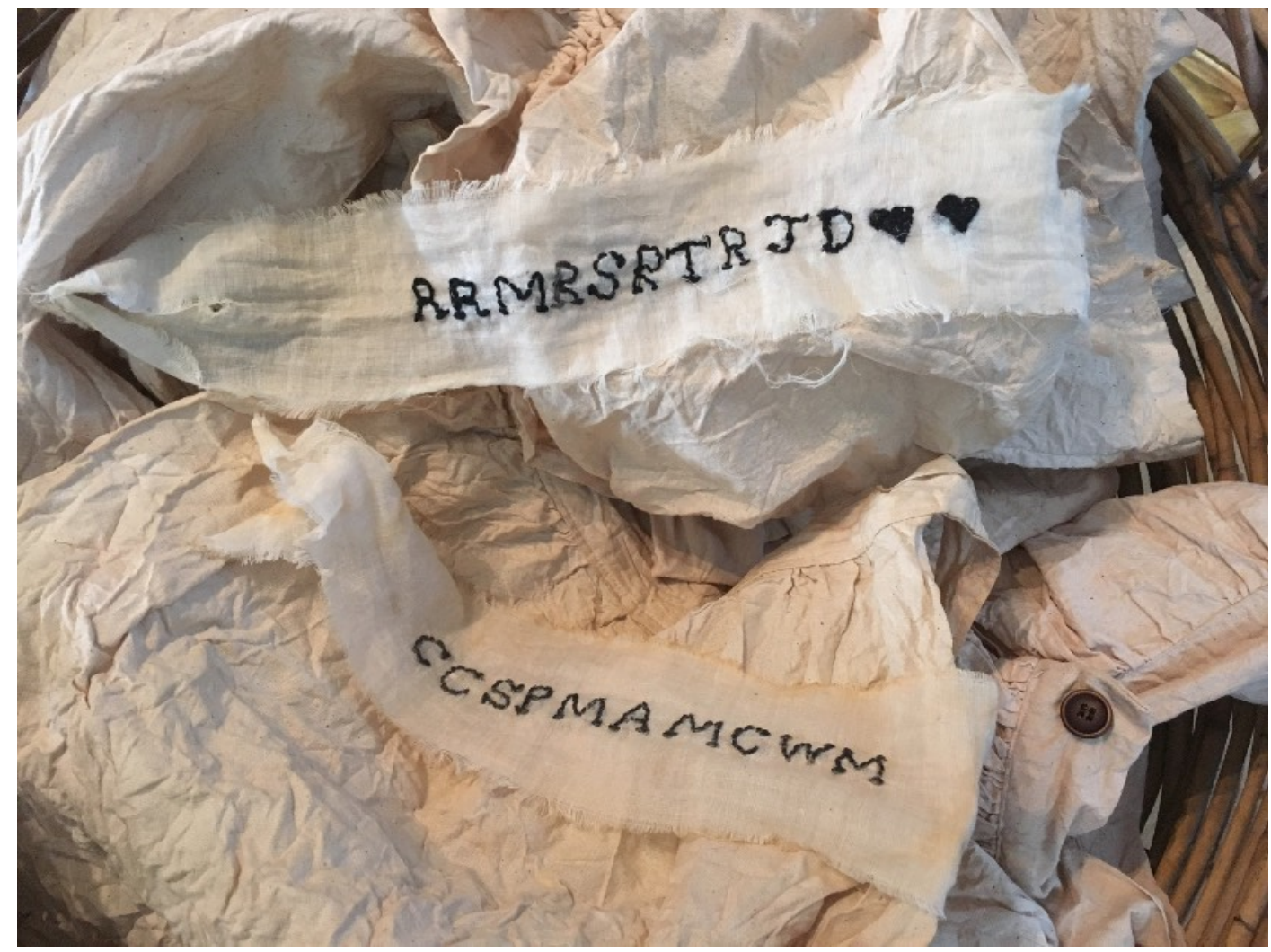

Figure 7. Skirts, bonnets and bands, original artwork by Louise Gwenneth Phillips

This stitching work was about making time for ethically and sensory knowing and being. Whole of body sensing of interconnectedness/interrelationality evokes ethicality, that is, "hospitality to the stranger threaded through oneself and through all being and non-being" (Barad, 2014, p. 163). In this space, self-interests dissipate and the attention is to "being with."

Through making, I could express ethicality and relationality with Nancy Ann's lived flesh encounters "to not just satisfy but also to intensify-to resonate and become more than itself...the creation of forms through which these materials come to generate and intensify sensation and thus directly impact living bodies, organs, nervous systems" (Grosz, 2008, p. 4).

Hold Louise's storymaking of belonging.

Breathe...

Now prepare to take in Lexi's storymaking of belonging. 


\section{Moving-With \& Moving-Through Homelands, Languages \& Memory: Belonging and Not-Belonging}

This work 4 is part of a larger inquiry that casts its gaze on human geographies and diaspora, particularly post-war migrations in Australia and the contemporary mass migrations in recent times from the MENA ${ }^{5}$ regions. Yet deeper than these surface concerns are the trauma and loss migrants and their children suffer, with the invisible wounds that resonate through histories and historicities.

There's an emptiness inside her eyes

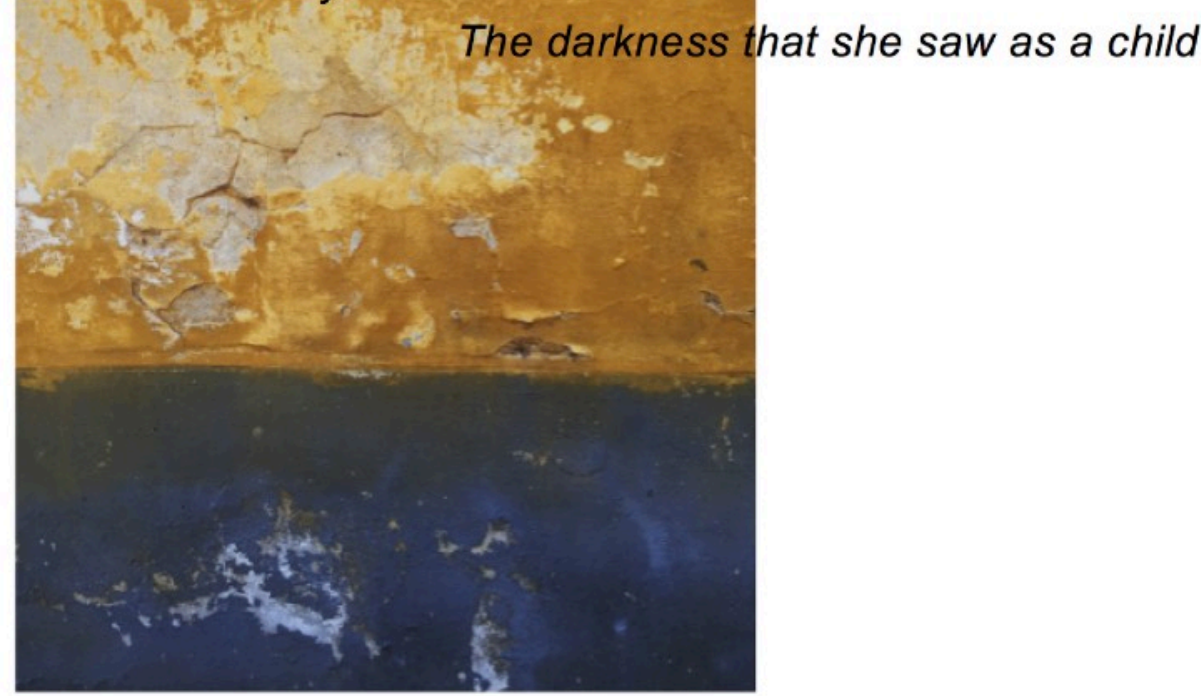

I have spent most of my adult life recovering from the trauma of lived difference and displacement, of not belonging. I have also spent most of my adult life trying to recover my heritage language (Guardado, 2002), a language that is so dense and unyielding I am yet to be successful. It is the strongest cultural tie I do not have, and I need it, to be whole (Hatoss, 2004). 
In 2015, at the same time that an unprecedented number of migrants and refugees reached Europe and the resultant crisis was the biggest in history, I returned to my parents' homeland of Hungary to try to recover their language, the language of all of my firsts, in the context of that language, their home.

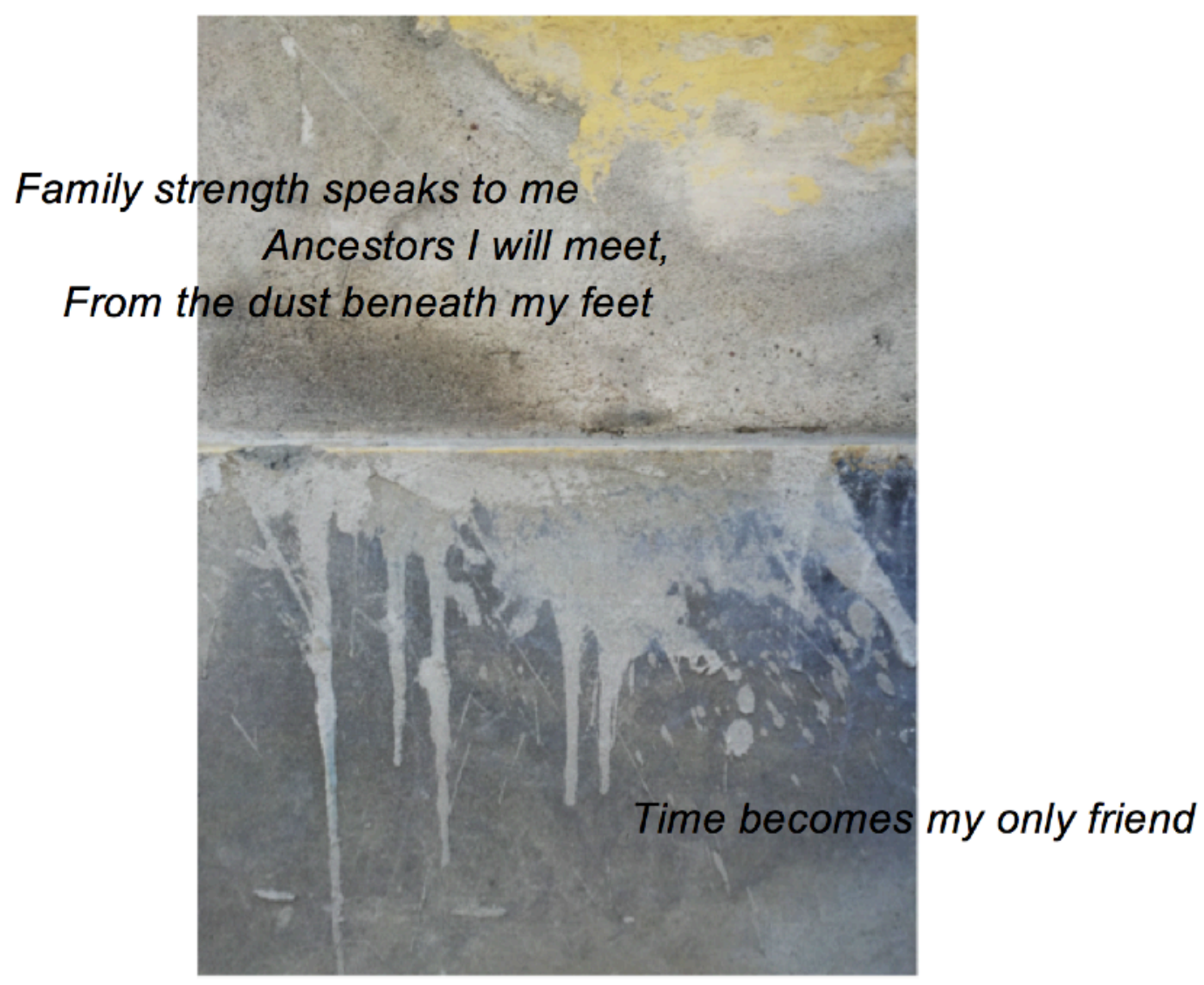

I came home to a place I didn't know, and again I was displaced (Joannidis, 2013). All around me was the language that I yearned for, the history that I had learnt, the dust of my ancestors under my feet. And yet, here as well, I was displaced and tormented in my not-belonging (Cutcher, 2015). It all seemed so slippery, just beyond my reach. I struggled with my language lessons every day, my teacher coaxing me ever so gently to persist (Lasczik Cutcher, 2018). 


\section{I try to follow her you see}

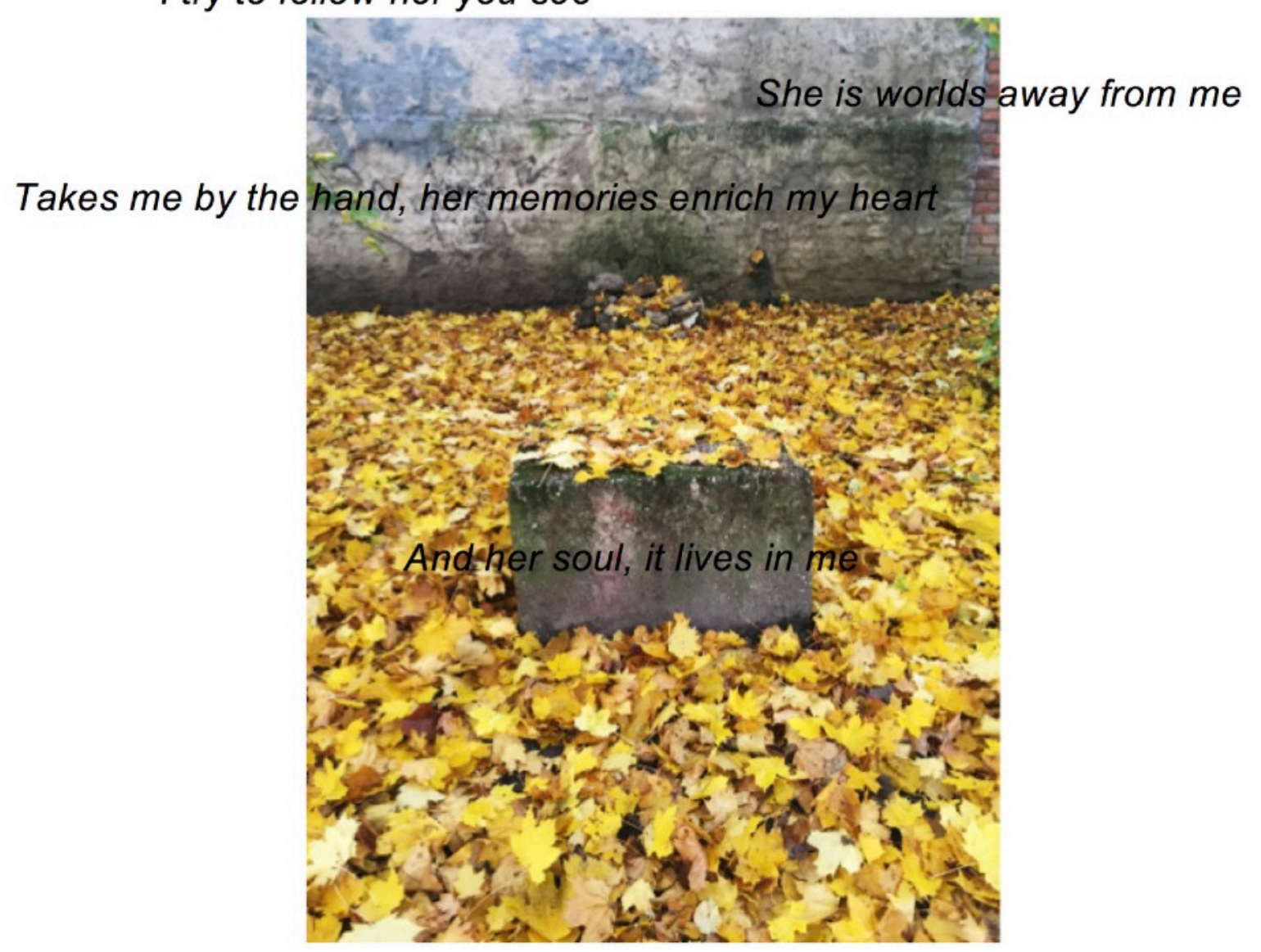

As an Australian I am blessed in so many ways; my privilege is not lost on me. I am grateful that my father and maternal grandparents made the decision to migrate (Cutcher, 2015). I also acknowledge that my experience is perhaps not as traumatizing as those of other marginalized people - and indeed, this has been said to me many times. But who is to say?

Hold Lexi's storymaking of belonging. 


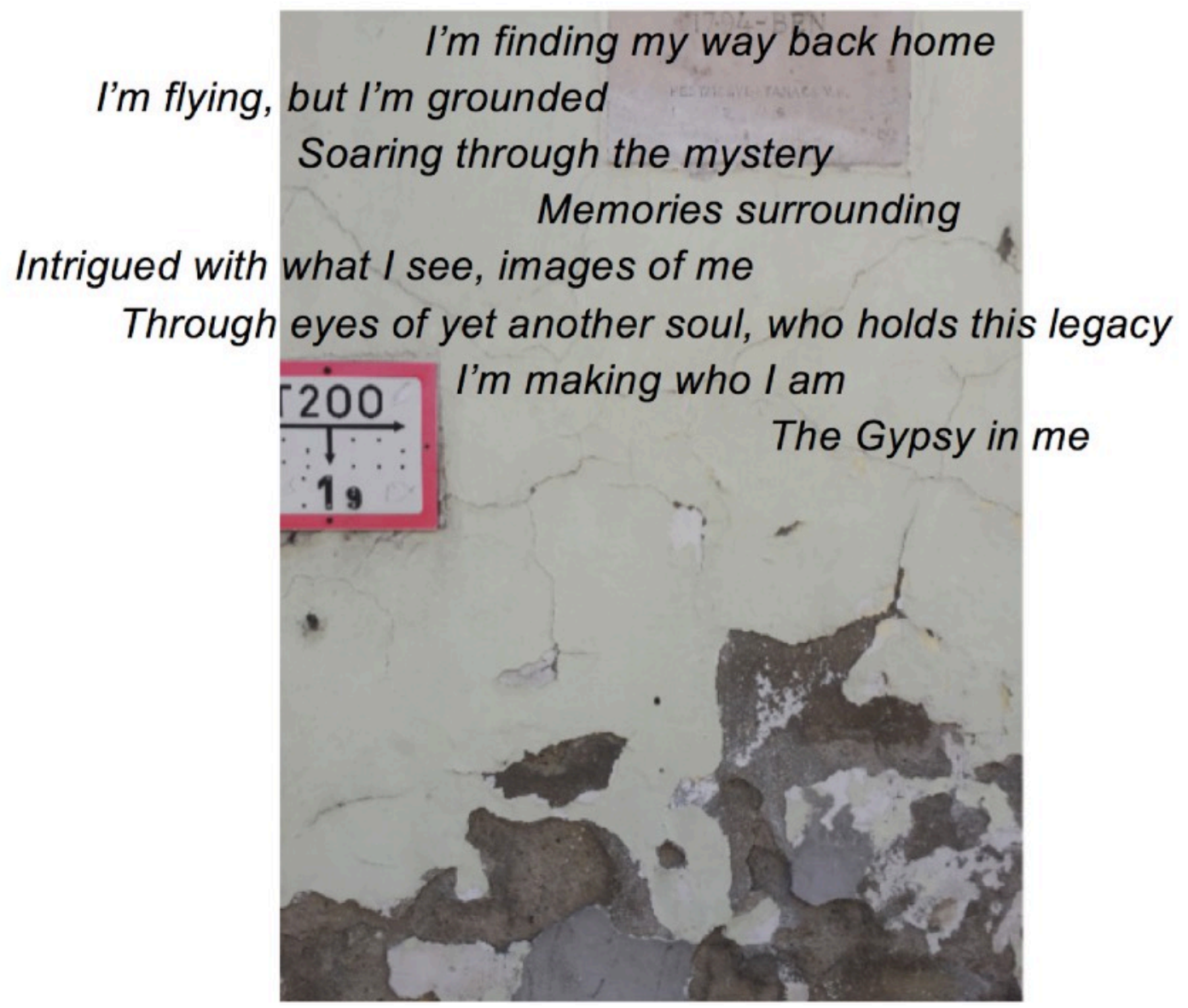

Breathe...

Now prepare to take in Ali's storymaking of belonging.

\section{They Walk Beside Me}

My making work is one of reimagining. I worked alone. I bought a canvas $91 \mathrm{x}$ $122 \mathrm{~cm}$. I considered the acrylic paints in my paintbox. I bought more black, purple and green. My daughter took a headshot photo of me three weeks after my $50^{\text {th }}$ birthday starting points. 


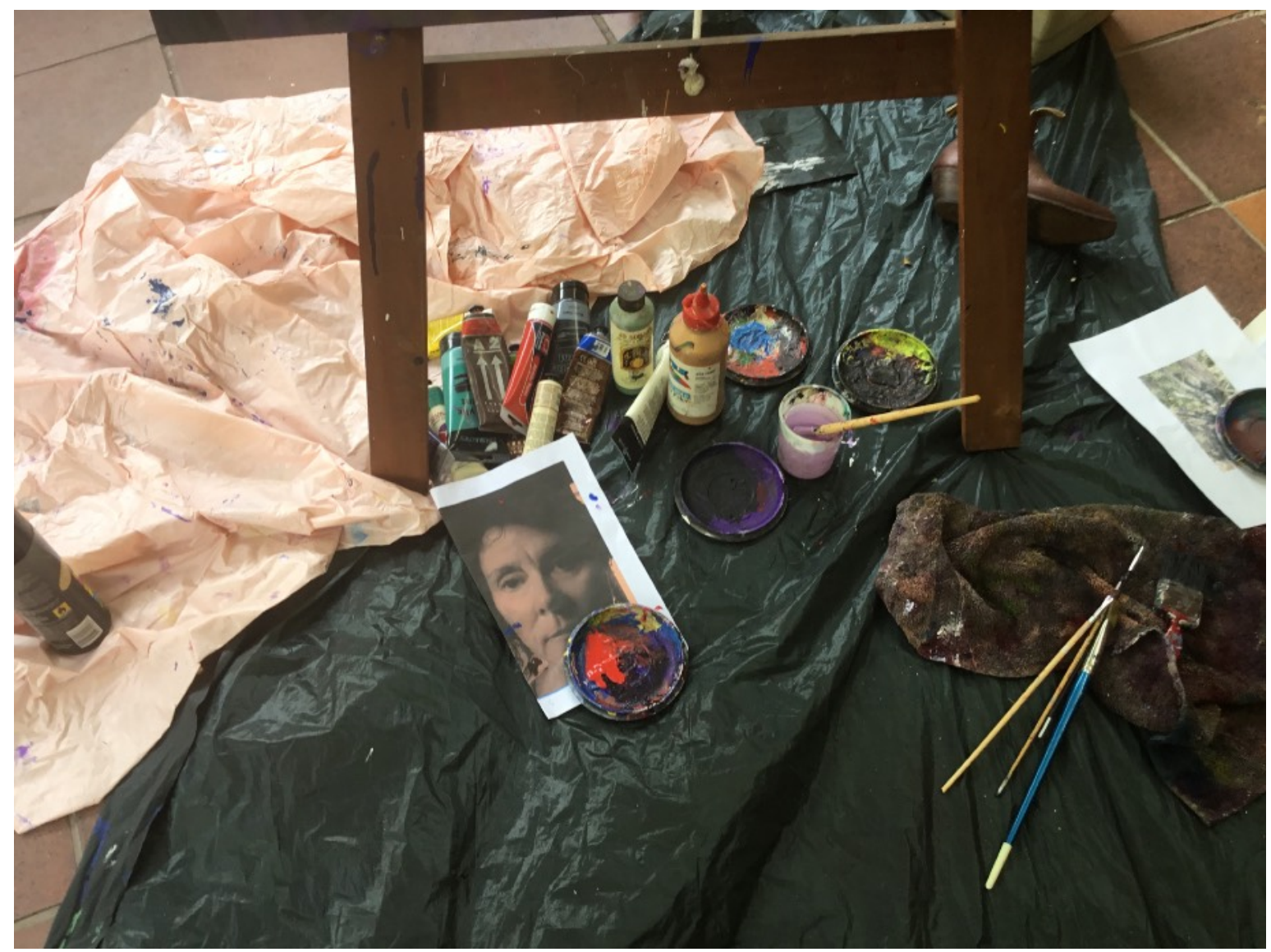

Figure 8. Starting points, Personal photo taken by Ali Black

This project, focused on examining ancestry and stories of belonging, invited much of me. It invited "beauty and truth" (Richardson, 1999, p. 660) as I struggled to remember and retell. Art helped me find a way to give testimony to memory and history. It offered a meditation space for engaging "art as witness" (Agosin, 1996, p.13-15) showing me how I might live with/without memory and somehow continue a narrative representing intimate relationships and recovering a sense of belonging. As artist/ researcher, I have, through this artmaking, been involved in "witness consciousness" (Walsh and Bai, 2015, p. 25) where creative and making processes have provided a contemplative space in which to bring my reflection and awareness-to "be-with" my lived experience in an act of "wit(h)nessing" (Snowber \& Bickel, 2015, p. 76-77). My artmaking through painting has enabled the exploration and representation of emotional, ecological and embodied ways of knowing about belonging. Through this crafting, I have opened the door to opportunities for physical and emotional holding. Past, present and future have merged and entangled. Contemplative and artistic practices have opened me to cosmic and spiritual energies and offered a sense of connectedness. They have called me as artist/researcher to "deeply listen and hold with great gentleness the sacredness of the work of creating" (Snowbar \& Bickel, p. 67). 
Where do I belong? My matriarchs are gone and their stories have disappeared with them.

I remember only fragments, traces, names. As I contemplated beginning this "making as method" to tell my stories, a feeling of dread lingered in my being, and an acute pain rose up within me. There are no stories I can tell. I have lost the stories of those who have gone before. On paper at my bedside, I write down the names that I know: Mary, Anna, Catherine, Pauline-Lizette, Carolyn, Alice, Isabella, Annie, Lena, Va, Mary-Alison, Jenifer. I savour the truth that I am named after my grandmothers, that I am Alison Lizette. I embody these names and these women. As my fingers touch the yellowing sheet music my Grandma loved and played on her piano before my mother was born, I realise the truth of the lyrics "I'll walk beside you."

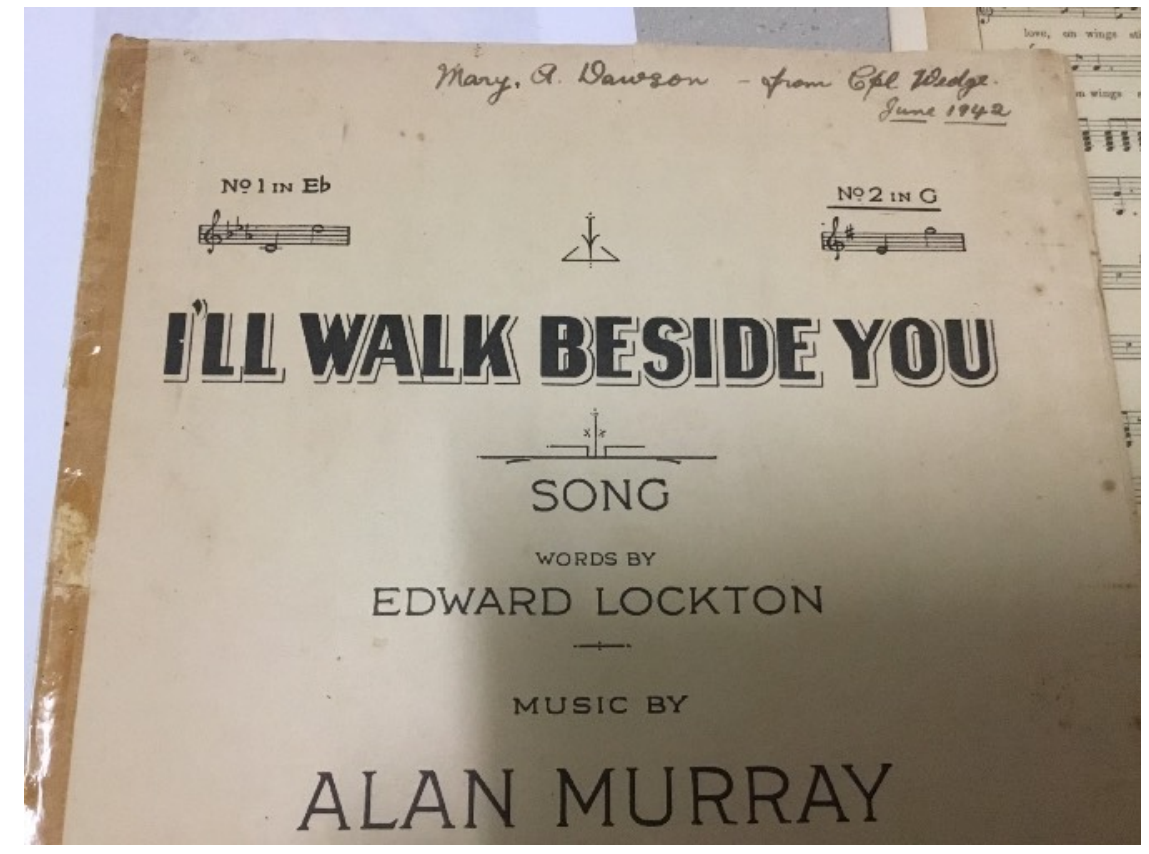

Figure 9. I sense the presence of the numinous, and realise they walk beside me, personal photo taken by Ali Black

This song and its essence become a social process for expression. It becomes a bridging space. A space of belonging. I imagine this music being passed from my grandmother, to my mother, to me, to my children, a message for our hearts, minds, bodies, souls: I walk with you. I walk beside you through the world today. I'll walk beside you through the passing years. Seeing my grandmother's handwriting cultivates memories of our close connection and our tender and deep relationship. It invites more of me. It invites an emotional response. Love. It causes me to consider singing the 
words as an extension of my painting. I sense my heart softening and I dare to believe that I am not alone. I never have been alone. I will never be alone.

These artful processes have taken me on a journey of healing and insight enabling me to engage deeply with the "extensive process that remembering implies", to "receive and feel history", and to "recognise and memorialise" my women ancestors (Agosin, 1996, p. 24-25). This inquiry and its made and found artefacts offer me ongoing sustenance, helping me relinquish my grief for the stories that have disappeared, and uncovering a way to tap into my DNA, to the ancestry that resides in my body, and that continues to shape my ways of knowing, what I care about, the meaning that I make. My painting offers a personalised and symbolised way to connect with hidden stories and identities, of travel, of connection with the earth and its terrain, of pain and displacement, of courage and freedom. This making as method has helped me remember and reclaim belonging, hope and identity via an aesthetic and embodied and spiritual listening process. With this art making process I have "hear[d] the invisible presence of the numinous" (Snowber \& Bickel, 2015, p. 86) and now hold new consciousness which I feel in my body and recognise in my artwork.

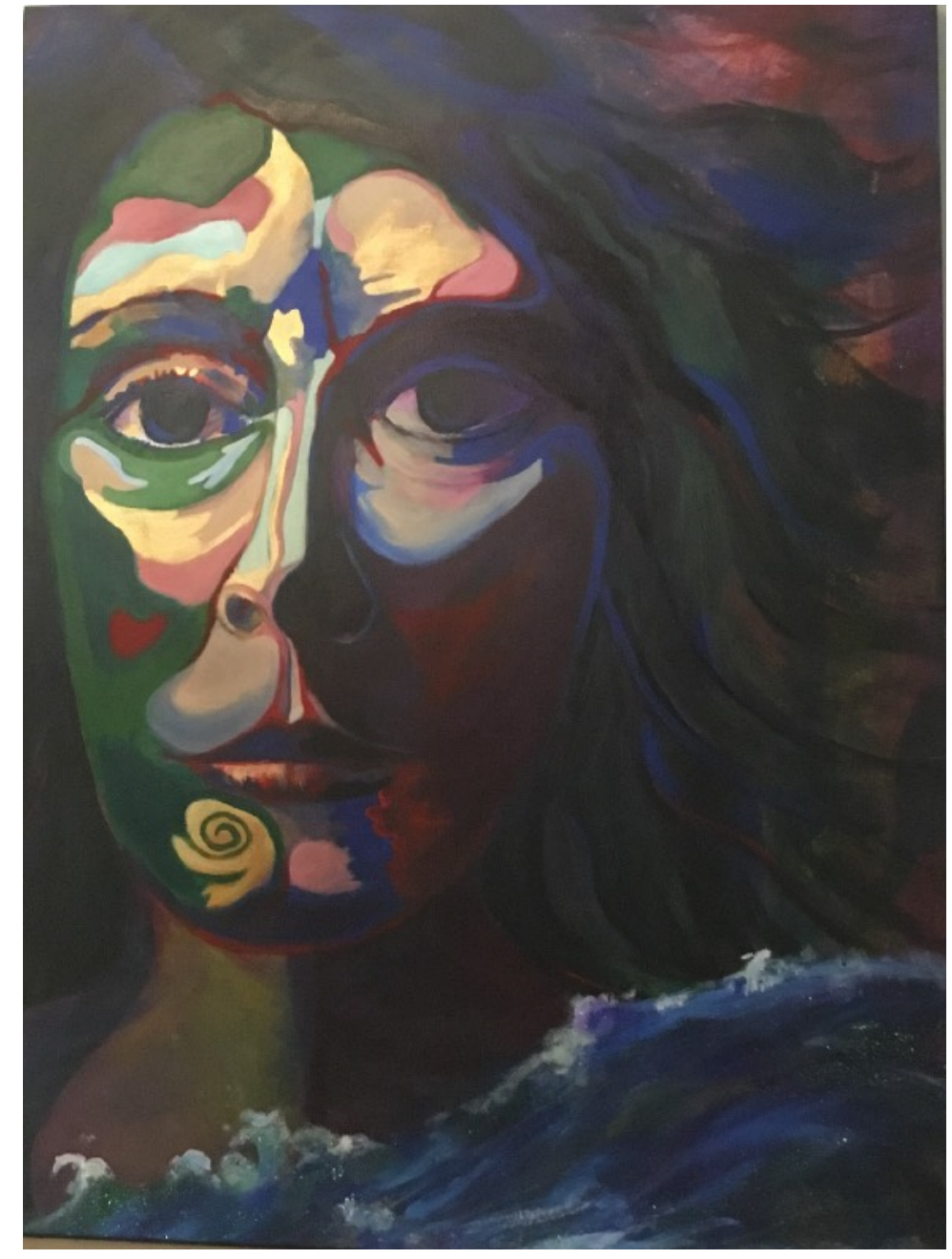

Figure 10. 'They walk beside me': The process/product of wit(h)nessing felt in body and represented in art, original artwork by Ali Black

Hold Ali's storymaking of belonging.

Breathe...

sit with all you have read...

Embody our collective storymaking... engage with y/our questions of belonging... stay... sit awhile... 


\section{Conclusion}

The making of the basket, the business of women, fibrous in its nature, cellular walls evolving, has metaphorically stood as the space from which Sistas have held themselves, held each other, with data, to make our stories, to make ourselves. Our making methodology in story mirrors the fibres, weaving the cellular, touching the essence of our desires on and under our skin, to be our skin, to know ourselves through ancestral data - stitching, threading, imaging, dancing, painting - to being. A Wiradjuri being for Robyn, cloak making of river and riverbank textured with river red gumtree, Murray cod, perch, duck, brown snake and snakelets, goanna - all be-(long)-ing in nature, in Aboriginal country, in family. For Ali storymaking methodology exercises the remembering of ancestry of body, cellular inside, all of its fibrous parts, not forgotten but walking beside. The interconnectedness reminds us we are not alone. Remembering is not without its pain, complex entanglements are hard to unknot - languages must be learnt as tongues have been displaced - let loose my tongue for the language is dense, Lexi (Alexandra) must belong. Finding belonging through a novel marriage - belonging to black, belonging to white and through experimental making, interrogations of data have been storied and stitched for Kim. Cellular pockets of disconnection are being remade. Whole. Our methodology makes whole some of our parts. For Tracey and Louise the reclamation of stories, the materiality of data, makes known the scarification left by colonization. There is stitching to be done. Whole of body sensing/dancing our locatedness, our identities. Collectively the authors bring to light a uniquely Australian experience. Our methodology re-makes the emptiness to fill the basket, to give voice in silence, gathering broken pieces to re-connect - ourselves. Our methodology embodied, provokes understandings. Ancestories displaced. Tangled belongings. 


\section{REFERENCES}

Agosín, M. (1996). Tapestries of hope, threads of love: The arpillera movement in Chile 1974-1994. Albuquerque, NM: University of New Mexico Press.

Barad, K. (2014). On touching - The unhuman that therfore I am (v1.1). In S. Witzgall \& K. Stakemeier (Eds.), Power of material/politics of materiality (pp. 153-164). Berlin: Diaphanes.

Cutcher, A. J. (2015). Displacement, identity and belonging: An auto/biographical and arts-based portrayal of ethnicity \& experience. Rotterdam, NL: Sense Publishers.

Deleuze, G. (1990). The logic of sense. [C. Boundas, Trans]. New York: Columbia University Press.

Grosz, E. (2008). Chaos, territory, art: Deleuze and the framing of the Earth. New York: Columbia University Press.

Guardado, M. (2002). Loss and maintenance of first language skills: Case studies of Hispanic families in Vancouver. Canadian Modern Language Review, 58(3) 341-363.

Hatoss, A. (2004). Multiculturalism and mother tongue maintenance-the case of the Hungarian diaspora in Queensland. Australian Review of Applied Linguistics, 27(2), 18-3.

Heckenberg, I. (2018, May 18/20). River music: Yindyamarra milawa bila.

Commissioned for performance Yindyamarra Bila Yiramal Ngurambang Milawa Wirramarri, Maranggaal in "Stories of Belonging," Brisbane, AU.

Heckenberg, R. (2016). Learning in place, cultural mapping and sustainable values on the Millawa Billa (Murray River). The Australian Journal of Indigenous Education, 45(1), 1-10. doi:10.1017/jie.2015.23

hooks, b. (1995). Writing autobiography. In M. Blair, J. Holland, \& S, Sheldon (Eds.), Identity and diversity: Gender and the experience of education (pp. 3-7). Clevedon, UK: Multilingual Matters. 
Joannidis, C. (2013). Homecoming. International Forum of Psychoanalysis 22(3), 133-141.

Lasczik Cutcher, A. (2018). Moving-with \& moving-through homelands, languages \& memory: An arts-based walkography. Rotterdam, NL: Brill Sense Publishers.

Libraries Tasmania Online Collection. (n.d.). Hope Surgeon's journal. Retrieved from https://stors.tas.gov.au/CON19-1-3\$init=CON19-1-3p135

MacLure, M. (2013). The wonder of data. Cultural Studies/Critical Methodologies, 13(4), 228-232.

McGahey, T. \& Lasczik Cutcher, A. (2015). Gypsy [Recorded by T. McGahey]. On Cloud 9 [CD Album]. Nashville, TN: Tahlia McGahey Productions.

Nicolacopoulos, T., \& Vassilacopoulos, G. (2014). Indigenous sovereignty and the being of the occupier: Manifesto for a white Australian philosophy of origins. Melbourne, AU: Re.Press.

Pink, S (2015). Doing sensory ethnography $\left(2^{\text {nd }} e d\right)$. Thousand Oaks, CA: Sage.

Phillips, L., \& Bunda, T. (2018). Research through, with and as storying. London, UK: Routledge

Richardson, L. (1999). Feathers in our cap. Journal of Contemporary Ethnography, 28(6), 660-668. doi:10.1177/089124199129023767

Snowber, C., \& Bickel, B. (2015). Companions with mystery: Arts, spirit, and the ecstatic. In C. Leggo, S. Walsh, \& B. Bickel (Eds.), Arts-based and contemplative practices in research and teaching: Honouring presence (pp. 67-87). New York, NY: Routledge.

Walsh, S., \& Bai, H. (2015). Writing witness consciousness. In C. Leggo, S. Walsh, \& B. Bickel (Eds.), Arts-based and contemplative practices in research and teaching: Honouring presence (pp. 24-44). New York, NY: Routledge. 


\section{ENDNOTES}

1 B.C. (Before Christ) signifies a critical moment within the Christian Calendar. B.C. here is reclaimed and renamed to Before Cook (that is Captain James Cook who is known to have "discovered" Australia) to signify a critical time within Aboriginal and Torres Strait Islander histories, societies and cultures in the Australian context. This time heralded sovereignty, peace, spiritual well-being and connectedness to our countries.

2 Gammon in Aboriginal vernacular means pretend, false, not real. The reference here is to the legislation which was named to "care" and "protect" Aboriginal children, adults, families and communities, but failed in this objective.

3 Dughai, in the language of the author, means white.

4 See Lasczik Cutcher, A. (2018). Moving-With \& Moving-Through Homelands, Languages \& Memory: An Arts-based Walkography. Rotterdam: Brill Sense Publishers. The images that follow are all from this book and they are presented as a visual essay. All images are taken by the author (Lasczik). All images are of Hungarian walls, taken by the author in 2015. They are not titled as figures because they are not figures, they are integral to the critical and theoretical positionings of the essay. As such, they are to be viewed as text - visual text. Also, please note that the words in the visual essay are from the song "Gypsy." This song is the bridge between two books: it is inspired by the prologue in my first book, Displacement, Identity and Belonging: An Arts-Based Portrayal of Ethnicity and Experience (2015), Sense Publishers, the prequel to Moving-With \& Moving-Through Homelands, Languages \& Memory: An Arts-based Walkography. Lyrics by Tahlia McGahey \& Alexandra Lasczik Cutcher. Music by Tahlia McGahey. Performed by Tahlia McGahey.

5 The Middle East \& North Africa. 